\title{
Factors Contributing to Microbial Growth in Food and Convalescent Carriers among Street Vendors in City of Mbeya, Mbeya Region, Tanzania
}

\author{
L.P. Meleki ${ }^{1}$, T.S.A. Tolly ${ }^{2}$, N-N. Judicate ${ }^{3}$ \\ ${ }^{1}$ Department of Life Science, The Open University of Tanzania, P.O. Box, 23409, Dar es-Salaam, Tanzania
}

\begin{abstract}
The study sought to explore the status of microbial contaminants in street vended food and the incubatory carriers among street food vendors conducted in Mbeya City in 2014. The questionnaires and observation checklists were administered whereas, bacteriological examination of stool specimen and food were collected from 96 street food vendors. The results showed that 21 (27\%) out of 78 of food samples collected and five out of 25 stool specimens were found with food borne disease pathogens. Some of the pathogens are not only among the top ten least wanted food borne diseases but also some vendors were convalescent carrier and multidrug resistant. The pathogens include Escherichia coli O157: H7, Staphylococcus aureus, Salmonella Typhi and Salmonella Typhimurium. The results showed that $70 \%$ of respondents had formal primary education, $27 \%$ had secondary school education, $1 \%$ had university education suggesting that majority of vendors never had basic knowledge on food safety training to better understand the concept of the food safety in relation to microbial contamination in food and human health carriers. The results of microbial quality of the food demonstrated that the food vendors had to offer unsafe food to their clients. The study identified infrastructure, food equipment, and casual helpers, presence of pests, holding temperature for food and storage, weak regulatory systems as a gap in Mbeya City Council. The outcome of this study can serve as a baseline data for management and improvement of the street food safety based on study area.
\end{abstract}

Keywords: microbial contaminants, food vendors, food born diseases and water activity

\section{Introduction}

The study was carried out on street food vendors and their food they sold in the City of Mbeya. The study based on four wards Ruanda, Sisimba, Uyole, and Igawilo in the City Mbeya. The study involves the application of two tools: the WHO five keys to safe food and five keys to growing safe fruits and vegetables. The five keys aimed at safeguarding food hygiene practice and promoting health by decreasing microbial contamination from food vendors and street vended food. The keys are 1) Keep Clean; 2) Use safe; raw materials and water 3) Cook food thoroughly; 4) Avoid cross contamination and 5) "Keep food at safe temperatures. The five keys practices presented in the paper aim at reducing microbial contamination resulting from biological, therefore do not address contamination by chemical or other hazards. However, the knowledge and technologies that can eliminate all food safety problems associated with the microbial contamination of food are not yet present (WHO, 2012).

The paper presents the new kit that practices to reduce microbial contamination of fresh fruits, vegetables, and cereals from fungal i.e. mycotoxins, during planting, growing, harvesting and storing. The Five keys are: 1) Practice good personal hygiene; 2) Protect fields from animal faecal contamination; 3) Use treated faecal waste; 4) Evaluate and manage risks from irrigation water and 5) Keep harvest and storage equipment clean and dry. Some microbial such aflatoxins can produce moulds, smell and/or discolorations while, others organisms hardly real produce any smell, discoloration, or any other changes you can detect with your senses. In addition, you will not even know they are there until you start to feel nauseous, stomach cramps or pain. The Keys have been practice by countries such Belize, Guatemala, and El Salvador (WHO, 2012 \& WHO, 2016).
In addition, the outbreak of Aflatoxicosis in Tanzania July to December 2016 of which 68 cases and 20 deaths Case Fatality Rate of $29.41 \%$ occurred and found reported by Aflatoxicosis Situation Updates and Response WHO Country Office, Tanzania on 11 January 2017. The affected regions were Dodoma and Manyara; this resulted from the poor production of peanuts and maize not kept in clean and dry storage equipment, poor food safety and improper handling of food (Zain, 2011 \& Nelson \& Zeratsky, 2012). The Aflatoxins according to Yard et al., (2013) are a fungal toxin that derived from some strains of Aspergillus flavus, they reported to taint an estimated one-quarter of agricultural products worldwide, with maize, cereals, and groundnuts being the most predisposed. This can be mitigated by application of five keys to growing safe fruits and vegetables as the case of Belize, Guatemala, and El Salvador (WHO, 2012 \& WHO, 2016).

\section{Factors that offer Microbial Growth in Food}

In generally most food contains sufficient nutrients to support microbial growth of which several factors encourage, prevent, or limit the growth of microorganisms in food; the most important are moisture, temperature, time, Oxygen, and $\mathrm{pH}$. These factors are broadly involved water activity, $\mathrm{pH}$, temperature, and relative humidity. The water activity varies very little with a temperature that supports microbial growth. The addition of solute decreases the water activity to less than one. The change in $\mathrm{pH}$ of a food with time may reflect microbial activity, and food that is poorly buffered does not resist changes in $\mathrm{pH}$, such as vegetables, may change $\mathrm{pH}$ values (Yusuf et al., 2012). Example for the $\mathrm{pH}$ of muscle from a rested animal may differ from that of a fatigued animal. 


\section{International Journal of Science and Research (IJSR) \\ ISSN (Online): 2319-7064}

Index Copernicus Value (2016): 79.57 | Impact Factor (2015): 6.391

Occasionally, food $\mathrm{pH}$ is not stationary; sometimes-other microbes' yeasts or moulds, $\mathrm{pH}$ may change and allow bacterial growth. The $\mathrm{pH}$ range of a microorganism is at the acidic while a maximum is at the basic end of the scale. Growth is maximal for a $\mathrm{pH}$ optimum; the most favorable conditions are time, temperature, $\mathrm{pH}$, and incubation period that every microorganism has a minimum, an optimum and a maximum $\mathrm{pH}$ for growth. Moving away from the $\mathrm{pH}$ optimum in either direction slows down microbial growth (Yusuf et al., 2012).

The greatest danger from microbes in food is associated with consumption of various sources of food that is mainly tainted with human and animal faeces, and other factors may encourage, prevent, or limit the growth of microorganisms in food. The water activity, $\mathrm{pH}$, and temperature may also be important. This paper focuses on organisms for which there is evidence, from outbreak studies or from prospective studies in non-outbreak situations, of disease being caused by ingestion of unsafe food. Risk factors associated with the human reason and preparation methods that give high prevalence of food borne diseases shown by various studies.

The widespread food borne pathogens that linked to that danger include Campylobacter Jejuni, Clostridium botulinum, perfringens, Escherichia coli O157: H7, Listeria Monocytogenes, Salmonella, Shigella, Vibrio cholera, Hepatitis "A", Norovirus, Cyclospora cayetanensis, Staphylococcus aureus, Campylobactor jejuni and Toxoplasma gondii (TEA, 2015). The hazard causes included improper holding temperatures, inadequate cooking, contaminated equipment, storage, food from an unsafe source and poor personal hygiene (Chilukoti, 2014).

\section{Vendors food borne disease pathogens carrier status}

Twenty-five human stool specimens were drawn from the four wards Ruanda, Sisimba, Uyole, and Igawilo showed that only five and specifically those drawn from Ruanda ward were contaminated with food borne diseases pathogens often implicated in diarrhoeal diseases. These include Escherichia coli O157: H7, Staphylococcus aureus, Salmonella Typhi and Salmonella Typhimurium that are not only among the 16 known food borne disease pathogens listed in Table 2 but also the top ten least wanted in food as they are known to fatal consequences to consumers of food the contaminated food. According to Thanh, (2015) Salmonella species, Escherichia coli, and Staphylococcus Aureus are antimicrobial-resistant pathogens bacteria. These included two isolates of Salmonella Typhi, one isolate of Escherichia coli 0157: H7, one isolate of Escherichia coli species, and one isolate of Salmonella Typhimurium.

In the study area, the most spread pathogens among the isolates were Salmonella species at $60 \%$ i.e. three-fifth of all isolates. However, no single stool sample food with more than one pathogens or with co-infections as some pathogen species may interact within the host (Diedrich, 2011). This anticipated that future studies might clarify valuable new information on the interesting subject of co-infection of protozoa with other pathogens. The carrier status is evidence that no food hygiene regulation was been complied with during the time of the study.

Table 1: Pathogens isolated in collected stool specimen

\begin{tabular}{|c|c|c|}
\hline SN & Ward & d Pathogen \\
\hline $\mathrm{A}_{1} 14$ & Ruanda & Escherichia coli $0157: \mathrm{H} 7 *$ \\
\hline$A_{1}-17$ & Ruanda & Escherichia coli \\
\hline $\mathrm{A}_{1}-03$ & Ruanda & Salmonella Typhi* \\
\hline $\mathrm{A}_{1-16}$ & $\mathrm{da}$ & Salmonella $\mathrm{Ty}$ \\
\hline $\mathrm{B}_{2-16}$ & Sisimba & Salmonella Typhi* \\
\hline \multicolumn{3}{|c|}{ Source Data collected in 2014} \\
\hline \multicolumn{3}{|c|}{$\begin{array}{l}\text { Note: i) Reading machine: BBL-Crystal Auto reader: cat. } \\
\text { no.245300 (BD, 2013) } \\
\text { ii) Isolates are taxonomically annotated } \\
\text { *List of top ten least wanted food borne pathogens: } \\
\text { Campylobacter, Clostridium botulinum, Escherichia coli } \\
\text { O157: H7, Listeria monocytogenes, Norovirus, Salmonella, } \\
\text { Staphylococcus aureus, Shigella, Toxoplasma gondii, Vibrio } \\
\text { vulnificus (TEA, 2012 and CFIA, 2016) }\end{array}$} \\
\hline
\end{tabular}

\subsection{Microbiological contaminants in food}

Of 78, various food samples collected 21 (27\%) had pathogens that can cause food borne diseases as shown in Table 2). These findings were somehow similar to several study findings by Campbell in (2011) South Africa; Schmidt in (2011) Canada; Githaiga in 2012 \& Nyamari in (2013) Kenya; Tiisekwa in (2013) Tanzania. The similar studies conducted in Tanzania include that of Njaya in (2013) Zimbabwe; Samapundo (2013) in Haiti; Ntomola in (2014) Tanzania; Omemu et al., in (2014) Nigeria; Girma in (2015) Ethiopia; Thanh in (2015) Vietnam.

One sample of sardines and cooked rice had Staphylococcus aureus 3\% two out of 78. Escherichia coli were isolated in two samples of cooked rice and in a sample of pickle-mixed vegetables. Bacillus cereus was isolated in a sample of cooked maize mixed with beans and lastly, Enterobacter cloacae were isolated in one cooked liver sample. In the other circumstance, two pathogens Acinetobacter baumannii and Acinetobacter haemolyticus were found in a cooked bean while Bacillus megaterium and Lactococcus raffinolactis found in a stiff porridge sample. This is contrary to the stool sample that single pathogen found in a stool sample presents no co-infection.

As the case of parasite interactions that include microbial interference when one bacterial species can further suppress the virulence or colonization of other bacteria, such as Pseudomonas aeruginosa suppressing pathogenic Staphylococcus aureus colony formation revealed by (Sievert et al., 2013). Of all isolates, only bacterial pathogens were isolated. Pathogens like viruses, protozoa, and helminths, which are commonly responsible for causing diarrhoeal diseases, were not isolated from the sample collected in the study area.

According to Acharya, (2012 \& 2015) indeed the above limitation was expected because of the laboratory capacity and specialty. Abdalla et al. (2009); Kok \& Balkaran (2014) suggest that in food processing, food borne microbes can be introduced from an infected person who handles the food, or by cross contamination from some other raw agricultural products and/or the in-plant environment. Abdalla et al. 


\section{International Journal of Science and Research (IJSR) \\ ISSN (Online): 2319-7064}

Index Copernicus Value (2016): 79.57 | Impact Factor (2015): 6.391

(2009); Kok \& Balkaran (2014), they further emphasize that contaminated hands are the most significant source of transfer microorganisms from food handler's faeces, face, skin, or other sites on to food. Escherichia coli, Salmonella species, Escherichia coli 0157: H7, Staphylococcus aureus, and Enterobacter Cloacae are potential food borne hazards with grave consequences.

Salmonella species, which is about 2 to $5 \%$ of untreated typhoid infections or those survivors of typhoid, can become chronic carriers and stand as a continuous spread (Ahmed, 20017). The frequency of occurrence of isolated pathogens in food suggests that consumers in Mbeya City were exposed to high risk of contracting diarrhoeal diseases through consumption of some street food cuisines. On the Other hand, other options suggested that to educate the consumers not to buy street food that sold in unauthorized places simply because of convenience or low pricing. Additional macro and microorganisms often found in food were not isolated not necessarily, because they were absent but because they were not targeted by the methods used for analysis in this study (FDA, 2012; Neza \& Centini, 2016). For this reason, the relative proportions of pathogenic to non-pathogenic strains in the study area are unknown.

Some of these bacteria are associated with food spoilage Klebsiella oxytoca and Yeast cells (Sperber \& Doyle, 2009 $\&$ FDA, 2012). Indeed the above limitation was expected because of the laboratory capacity and specialty. Only (6\%) five out of 78 samples were drawn from food that found kept at the optimal temperatures of $63^{\circ} \mathrm{C}$. In principle, one must apply thermometers to make sure that the temperature of the refrigerator is $40^{\circ} \mathrm{F}$ or lower and the temperature of the freezer is $0^{\circ} \mathrm{F}$ or less. Canadian Food Inspection Agency (CFIA, 2016) demonstrates that bacteria can grow in the danger zone between $4^{\circ} \mathrm{C}$ and $60^{\circ} \mathrm{C}\left(40^{\circ} \mathrm{F}\right.$ to $\left.140^{\circ} \mathrm{F}\right)$. While, raw food such as veal steaks, chops, and roasts should be cooked to a least an internal temperature of $63^{\circ} \mathrm{C}$ to $74^{\circ} \mathrm{C}$ and $85^{\circ} \mathrm{C}\left(145^{\circ} \mathrm{F}\right.$ to $165^{\circ} \mathrm{F}$ and $\left.185^{\circ} \mathrm{F}\right)$ for a whole chicken, turkey, and duck (CFIA, 2016). This suggests that there was poor food holding and storage temperature that can facilitate the microbial growth.

Summarising Table 1: above it may be stated that, (20\%) five out of 25 pathogens isolated in vendors' stool specimens and $27 \%$ (21 out of 780 ) food samples are among the top 10 public health pathogens of importance in food safety. These pathogens are known to cause serious food poisoning according to (CFIA (2016); Adem et al. (2008); Khanjar \& Alwan (2014). The carrier status in Ruanda ward and the wide spread confirmation of food contaminated with food borne microbes in the study area shows that there is a potential risk for diarrhoeal diseases outbreaks in Mbeya City and particularly in Ruanda ward. The infected vendors may have been victims of an earlier outbreak who came back to vending food without full recovery followed by nonclearance by a reliable medical examination protocol or were new comers who may get into food vending business while infected.

In this case, they both should have been cleared by a reputable and reliable medical examination before engagement, as the law requires. On the other hand, they may have been victims of an ongoing outbreak in Mbeya City or elsewhere that was yet to become publicly noticeable. In both cases, it shows a gap within the City Health Authorities pro-activeness in food hygiene protocols and needs to be redressed.

Table 2: Pathogens isolated in various food samples

\begin{tabular}{|c|c|c|c|}
\hline $\begin{array}{l}\text { sample } \\
\text { code }\end{array}$ & Ward & Food Types & Isolated pathogen \\
\hline $\mathrm{A}_{2}-12$ & Ruanda & Cooked liver & Enterobacter cloacae \\
\hline $\mathrm{B}_{2}-04$ & Sisimba & Cooked beans & $\begin{array}{l}\text { Acinetobacter baumannii and } \\
\text { Acinetobacter haemolyticus }\end{array}$ \\
\hline $\mathrm{B}_{2}-04$ & Sisimba & $\begin{array}{l}\text { Stiff porridge } \\
\text { (Ugali) }\end{array}$ & $\begin{array}{l}\text { Bacillus megaterium and } \\
\text { Lactococcus raffinolactis }\end{array}$ \\
\hline $\mathrm{B}_{2}-07$ & Sisimba & Chicken & Staphylococcus intermedius \\
\hline $\mathrm{B}_{2}-23$ & Sisimba & $\begin{array}{l}\text { Cooked maize } \\
\text { with beans }\end{array}$ & Bacillus cereus \\
\hline $\mathrm{C}_{2}-10$ & Uyole & Cooked rice & Escherichia coli \\
\hline $\mathrm{C}_{2}-06$ & Uyole & $\begin{array}{c}\text { Pickles (raw } \\
\text { vegetable mixed) }\end{array}$ & Escherichia coli \\
\hline $\mathrm{B}_{2}-16$ & Sisimba & $\begin{array}{c}\text { Mandazi } \\
\text { (African buns) }\end{array}$ & Enterobacter asburiae \\
\hline $\mathrm{B}_{2}-15$ & Sisimba & Porridge & Escherichia coli \\
\hline $\mathrm{D}_{2}-11$ & Igawilo & $\begin{array}{l}\text { Cooked pork } \\
\text { soup }\end{array}$ & Klebsiella \\
\hline $\mathrm{C} 2-17$ & Uyole & Sour milk & Hasnia alivei \\
\hline $\mathrm{A}_{2}-02$ & Ruanda & Rice & Escherichia coli \\
\hline $\mathrm{A}_{2}-10$ & Ruanda & $\begin{array}{c}\text { Pickles (raw } \\
\text { vegetable mixed) }\end{array}$ & Enterococcus faecium \\
\hline $\mathrm{A}_{2}-25$ & Runda & Chips & Klebsiella pneumoniae \\
\hline $\mathrm{A}_{2}-22$ & Ruanda & Sardines & Staphylococcus aureus* \\
\hline $\mathrm{A}_{2}-27$ & Ruanda & Sour milk & Yeast cells \\
\hline $\mathrm{C}_{2}-20$ & Uyole & Rice & Staphylococcus aureus* \\
\hline $\mathrm{C}_{2}-16$ & Uyole & Juice & Enterobacter aerogenes \\
\hline $\mathrm{A}_{2}-19$ & Ruanda & Meat/fish & Corynebacterium bovis \\
\hline \multicolumn{4}{|c|}{ Source Data collected in 2014.} \\
\hline \multicolumn{4}{|c|}{$\begin{array}{l}\text { Note: i) Reading machine: BBL-Crystal Auto reader: cat. no. } \\
245300 \text { (BD, 2013) } \\
\quad \text { ii) Isolates are taxonomically annotated } \\
\text { *List of top ten least wanted food borne pathogens: } \\
\text { Campylobacter, Clostridium botulinum, Escherichia coli O157: } \\
\text { H7, Listeria monocytogenes, Norovirus, Salmonella, } \\
\text { Staphylococcus aureus, Shigella, Toxoplasma gondii and Vibrio } \\
\text { vulnificus, (TEA, } 2012 \text { and CFIA, 2016). }\end{array}$} \\
\hline
\end{tabular}

The fungal toxins that produce Aspergillus flavus found mainly in maize, cereals, groundnuts by cooking can withstand the high temperature of more than $180^{\circ} \mathrm{C}$ (Yard et al., 2013). However, aflatoxins in food can be control best achieved by measures designed to prevent the contamination of crops in the field and during storage, or detection and removal of contaminated material from the food supply chain. These fungal toxins that produce Aspergillus flavus are responsible for aflatoxicosis outbreaks in East Africa countries including Kenya and recently Tanzania of which 68 cases and 20 deaths. The affected regions were Dodoma and Manyara; this resulted from the poor production of peanuts and maize not kept in clean and dry storage equipment, poor food safety and improper handling of food (Zain, 2011 \& Nelson \& Zeratsky, 2012).

The Aflatoxins according to Yard et al., (2013) are a fungal toxin that derived from some strains of Aspergillus flavus, they reported to taint an estimated one-quarter of agricultural products worldwide, with maize, cereals, and groundnuts being the most predisposed. This can be mitigated by

\section{Volume 6 Issue 12, December 2017}




\section{International Journal of Science and Research (IJSR) \\ ISSN (Online): 2319-7064}

Index Copernicus Value (2016): 79.57 | Impact Factor (2015): 6.391

application of five keys to growing safe fruits and vegetables the case of Belize, Guatemala, and El Salvador (WHO, 2012 $\&$ WHO, 2016).The experience of Belize, Guatemala, and El Salvador in successful adaptation of these keys may be suitable for controlling aflatoxicosis in Tanzania and other settings with similar nature.

While in the case of cholera, the adaptation which, will suit cholera setting by training food street vendors, school children, and community on five keys to safe food, this has worked in Haiti, Comoros, Angola, Gambia, Mozambique, Guinea, Botswana and the Democratic Republic of Congo is useful. Controlling microbial growth in food is not a once and all activity it needs multi-interventions that start from farm to dinning. The mnemonic conditions such moulds and others forcing the monitoring being throughout food supply chains to final consumers.

Table 3: Water activity $\left(a_{w}\right)$ value for microbial growth

\begin{tabular}{|c|c|c|c|}
\hline $\begin{array}{c}\text { Food poisoning } \\
\text { organisms }\end{array}$ & $\begin{array}{c}\text { Water } \\
\text { Activity } \\
\left(a_{\mathrm{w}}\right)\end{array}$ & $\begin{array}{c}\text { Food Borne Infectious } \\
\text { Organisms }\end{array}$ & $\begin{array}{c}\text { Water } \\
\text { Activity }\left(\mathrm{a}_{\mathrm{w}}\right)\end{array}$ \\
\hline $\begin{array}{l}\text { Clostridium } \\
\text { botulinum A }\end{array}$ & 0.95 & $\begin{array}{l}\text { Clostridium } \\
\text { perfringens }\end{array}$ & 0.95 \\
\hline $\begin{array}{l}\text { Clostridium } \\
\text { botulinum B }\end{array}$ & 0.94 & $\begin{array}{c}\text { Escherichia coli } 0157: \\
\text { H7 }\end{array}$ & 0.95 \\
\hline $\begin{array}{l}\text { Clostridium } \\
\text { botulinum } \mathrm{E}\end{array}$ & 0.97 & Vibrio cholera & 0.95 \\
\hline Bacillus cereus & 0.95 & Salmonella species & 0.94 \\
\hline $\begin{array}{c}\text { Campylobacter } \\
\text { coli }\end{array}$ & 0.95 & $\begin{array}{c}\text { Vibrio } \\
\text { parahaemolyticus }\end{array}$ & 0.94 \\
\hline $\begin{array}{c}\text { Campylobacter } \\
\text { jejuni }\end{array}$ & 0.98 & Yersinia enterocolitica & 0.96 \\
\hline $\begin{array}{c}\text { Listeria } \\
\text { monocytogenes }\end{array}$ & 0.92 & Aspergillus flavus & 0.82 \\
\hline $\begin{array}{c}\text { Staphylococcus } \\
\text { aureus }\end{array}$ & 0.86 & & \\
\hline
\end{tabular}

Sometimes food we feel affection for and count on for good health are contaminated with microorganisms that cause sickness and can be deadly for certain people. Food contamination can occur in many different ways. Four main causes of food contamination are not washing hands, crosscontamination as the process of transferring contaminants from one food contact surface to another improper storage and cooking temperatures and/or contamination by animal wastes. The contaminants can be divided into three categories: physical, chemical, and biological, demonstrated in Table 4. This paper is based mainly on biological aspects that microbes are responsible for a large number of food borne diseases.

Table 4: Biological, chemical, and physical hazards contaminants

\begin{tabular}{|c|c|c|}
\hline SN & Types & Contamination hazards \\
\hline 1) & Biological & $\begin{array}{l}\text { Pathogenic bacteria, e.g. Escherichia coli } \\
0157: \text { H7, Salmonella species, usually } \\
\text { associated with faecal contamination from } \\
\text { warm-blooded animals, or others, e.g. } \\
\text { Listeria monocytogenes, Clostridium } \\
\text { botulinum commonly found in contaminated } \\
\text { soil, water, and ruminants }\end{array}$ \\
\hline & & Naturally occurring plant toxins, e.g. \\
\hline
\end{tabular}

\begin{tabular}{|c|c|c|}
\hline \multirow[t]{4}{*}{$\mathrm{SN}$} & \multirow[t]{4}{*}{ Types } & \multirow{3}{*}{$\begin{array}{l}\text { Contamination hazards } \\
\text { alkaloids, cyanogens glycosides } \\
\text { Fungal, e.g. ergot, mycotoxins such as } \\
\text { aflatoxins and ochratoxins }\end{array}$} \\
\hline & & \\
\hline & & \\
\hline & & $\begin{array}{l}\text { Parasites, e.g. Cyclospora, Entamoeba, } \\
\text { Giardia, Cryptosporidium }\end{array}$ \\
\hline & & $\begin{array}{l}\text { Viruses, e.g. hepatitis A, Norwalk virus, } \\
\text { Rotavirus }\end{array}$ \\
\hline & & $\begin{array}{l}\text { Neurodegenerative disease e.g. prions cause } \\
\text { Bovine spongiform encephalopathy (BSE, } \\
\text { or "mad cow disease" is a prion disease in } \\
\text { cattle }\end{array}$ \\
\hline \multirow[t]{3}{*}{ 2) } & \multirow[t]{3}{*}{ Chemical } & $\begin{array}{l}\text { Pesticide, insecticide and fungicide residues } \\
\text { (international food law includes maximum } \\
\text { residue levels for named compounds to be } \\
\text { used on specific fruit and vegetables) }\end{array}$ \\
\hline & & $\begin{array}{l}\text { Heavy metals, e.g. zinc, lead, aluminum, } \\
\text { cadmium, and mercury }\end{array}$ \\
\hline & & $\begin{array}{l}\text { Mineral oils, e.g. diesel, grease, hydraulic } \\
\text { oil }\end{array}$ \\
\hline \multirow[t]{4}{*}{ 3) } & \multirow[t]{4}{*}{ Physical } & Glass, metal, stones \\
\hline & & Wood and twigs \\
\hline & & Pieces of bone and plastic \\
\hline & & Staple wire, hair, and dust \\
\hline
\end{tabular}

Source: Types food contaminants adapted from Texas Education Agency (2014) \& (2015)

In Food Safety and Sanitation Class, six conditions suggested by Texas Education Agency (TEA, 2014 \& 2015) which bacteria may need to grow, its acronymically is abbreviated as "FAT TOM" it stand as Food, Acidity, Temperature, Time, Oxygen, and Moisture. FAT TOM is a mnemonic device that portrayed in Table 5 is used in the food service industry to describe the six factors that contribute to food spoilage, favourable conditions required for the growth of food borne pathogens (TEA, 2015). In one extreme, these organisms do not real produce any smell, discoloration, or any other changes you can detect with your senses. You will not even know they are there until you start to feel nauseous, stomach cramps or pain.

\section{The theory of Water Activity $\left(a_{w}\right)$ and food borne diseases}

The physical property of Water Activity $\left(\mathrm{a}_{\mathrm{w}}\right)$ has direct influences on food storage stability because of some deteriorate processes in food are mediated by water. The chemical potential of $\left(a_{w}\right)$ is related to the osmotic pressure of an aqueous solution. When a substance such as salt is dissolved in water, the water activity is reduced (Sevenich et al., 2015). Curing food with salt and sugar can also dispossess bacteria of the water they require. This is done through osmosis process. When applied to a food's external, salt and sugar pull moisture from the inside of the food to the surface, where it evaporates. Salt and sugar also bring on osmosis with the bacteria themselves by sucking the water out of them through their own cell walls, killing them by sunstroke. On the other hand, heat up food to $165^{\circ} \mathrm{F} 74^{\circ} \mathrm{C}$ or for at least 30 seconds is enough to wipe out any dangerous bacteria it might contain. This is why salting is an ancient way of preserving food. The water activity is the amount of moisture in food that activates the bacteria growth. The formula term of $\left(a_{w}\right)$ is the ratio of the water vapour pressure of the food or solution (p) to that of pure water (po) at the same temperature: $\left[\mathrm{a}_{\mathrm{W}}=\mathrm{p} / \mathrm{po}\right.$ ] (Sevenich et al., 2015).

\section{Volume 6 Issue 12, December 2017}




\section{International Journal of Science and Research (IJSR) \\ ISSN (Online): 2319-7064 \\ Index Copernicus Value (2016): 79.57 | Impact Factor (2015): 6.391}

The water activity scale ranges from 0 to 1 as shown in Table 3. It suggested that the higher the value, the most available moisture in the food. Water activity is a major reason for preventing or limiting the growth of bacteria causing food or borne diseases. Food borne pathogens cannot grow under water activity of 0.85 . In Table 3 , almost listed food borne pathogens have water activity above 0.92 with exception of Staphylococcus aureus 0.85 and aflatoxin such as Aspergillus flavus 0.82 have water activity below 0.86 .

Table 5: The six conditions that promote the growth of foodborne pathogens

\begin{tabular}{|c|c|c|}
\hline \multicolumn{2}{|c|}{$\begin{array}{l}\text { Mnemonic } \\
\text { Conditions }\end{array}$} & Narration of factors \\
\hline $\mathbf{F}$ & Food & $\begin{array}{c}\text { There are sufficient nutrients available that promote the growth of microorganisms. Protein-rich foods, such as meat, } \\
\text { milk, eggs and fish are most susceptible to pathogens }\end{array}$ \\
\hline $\mathbf{A}$ & Acid & $\begin{array}{l}\text { Foodborne pathogens require a slightly acidic } \mathrm{pH} \text { level of 4.6-7.5, while they thrive in conditions with a } \mathrm{pH} \text { of } 6.6- \\
\text { 7.5. The United States Food and Drug Administration's (FDA) regulations for acid/acidified foods require that the } \\
\text { food be brought to } \mathrm{pH} 4.5 \text { or below. }\end{array}$ \\
\hline $\mathbf{T}$ & Temperature & $\begin{array}{l}\text { Food-borne pathogens grow best in temperatures between } 41 \text { to } 135 \mathrm{~F} \text { ( } 5 \text { to } 57 \mathrm{C}) \text {, a range referred to as the } \\
\text { temperature danger zone (TDZ). They increase in temperatures that are between } 70 \text { to } 104 \mathrm{~F}(21 \text { to } 40 \mathrm{C}) \text {. }\end{array}$ \\
\hline $\mathbf{T}$ & Time & $\begin{array}{l}\text { Food-borne pathogens grow best in temperatures between } 41 \text { to } 135 \mathrm{~F}(5 \text { to } 57 \mathrm{C}) \text {, a range referred to as the } \\
\text { temperature danger zone (TDZ). They increase in temperatures that are between } 70 \text { to } 104 \mathrm{~F}(21 \text { to } 40 \mathrm{C}) \text {. }\end{array}$ \\
\hline $\mathbf{O}$ & Oxygen & $\begin{array}{c}\text { Almost all foodborne pathogens are aerobic, that is requiring oxygen to grow. Some pathogens, such as Clostridium } \\
\text { botulinum, are anaerobic requiring no oxygen. }\end{array}$ \\
\hline $\mathbf{M}$ & Moisture & $\begin{array}{l}\text { Water is essential for the growth of foodborne pathogens; water activity }\left(\mathrm{a}_{\mathrm{w}}\right) \text { is a measure of the water available for } \\
\text { use on a scale of } 0 \text { to 1.0. Foodborne pathogens grow best in foods that have }\left(\mathrm{a}_{\mathrm{w}}\right) \text { between } 0.95 \text { and 1.0. FDA } \\
\text { regulations for canned foods require } \mathrm{a}_{\mathrm{w}} \text { of } 0.85 \text { or below. }\end{array}$ \\
\hline
\end{tabular}

Source: Texas Education Agency (2014 \& 2015).

The various pathogens are critical and fatal in the prevention as some are listed in Table 3. Many of these pathogens have the different duration that can persist on dry inanimate object surfaces that can span for more than five years. Therefore, it is difficult to realize the risk of contamination of some diseases as when and where the risk occurred.

Table 6: Persistence time of various pathogenic bacteria on dry inanimate surfaces

\begin{tabular}{|c|c|c|}
\hline SN & Type of bacteria & Duration of persistence on dry surfaces \\
\hline 1 & Acinetobacter spp. & 3 days to 5 months \\
\hline 2 & Bordetella pertussis & $3-5$ days \\
\hline 3 & Campylobacter jejuni & Up to 6 days \\
\hline 4 & Clostridium difficile (spores) & 5 months \\
\hline 5 & Chlamydia pneumoniae, Chlamydia trachomatis & $\leq 30$ hours \\
\hline 6 & Chlamydia psittaci & 15 days \\
\hline 7 & Corynebacterium diphtheriae & 7 days -6 months \\
\hline 8 & Corynebacterium pseudotuberculosis & $1-8$ days \\
\hline 9 & Escherichia coli and Escherichia coli 057: H7 & 1.5 hours -16 months \\
\hline 10 & Enterococcus spp. including VRE and VSE & 5 days -4 months \\
\hline 11 & Haemophilus influenza & 12 days \\
\hline 12 & Helicobacter pylori & $\leq 90$ minutes \\
\hline 13 & Klebsiella spp. & 2 hours to $>30$ months \\
\hline 14 & Listeria spp. & 1 day - months \\
\hline 15 & Mycobacterium bovis & $>2$ months \\
\hline 16 & Mycobacterium tuberculosis & 1 day -4 months \\
\hline 17 & Neisseria gonorrhoeae & $1-3$ days \\
\hline 18 & Proteus vulgaris & $1-2$ days \\
\hline 19 & Pseudomonas aeruginosa & $\begin{array}{l}6 \text { hours }-16 \text { months; on } \\
\text { dry floor: } 5 \text { weeks }\end{array}$ \\
\hline 20 & Salmonella typhi & 6 hours -4 weeks \\
\hline 21 & Salmonella typhimurium & 10 days -4.2 years \\
\hline 22 & Salmonella spp. & 1 day \\
\hline 23 & Serratia marcescens & 3 days -2 months; on dry floor: 5 weeks \\
\hline 24 & Shigella spp. & 2 days -5 months \\
\hline 25 & Staphylococcus aureus, including MRSA & 7 days -7 months \\
\hline 26 & Streptococcus pneumoniae & $1-20$ days \\
\hline 27 & Streptococcus pyogenes & 3 days -6.5 months \\
\hline 28 & Vibrio cholerae & $1-7$ days \\
\hline \multicolumn{2}{|c|}{ Type of fungus } & Duration of persistence on dry surface \\
\hline 1 & Candida albicans & $1-120$ days \\
\hline 2 & Candida parapsilosis & 14 days \\
\hline 3 & Torulopsis glabrata & $102-150$ days \\
\hline
\end{tabular}

\section{Volume 6 Issue 12, December 2017 www.ijsr.net}

Licensed Under Creative Commons Attribution CC BY 


\section{International Journal of Science and Research (IJSR) \\ ISSN (Online): 2319-7064 \\ Index Copernicus Value (2016): 79.57 | Impact Factor (2015): 6.391}

Note: i) spp. = Species; VRE= vancomycin-resistant Enterococcus; VSE = vancomycin-sensitive Enterococci; MRSA= Methicillinresistant Staphylococcus aureus ii) Italic Roman typefaces are presented in taxa annotation

This complexity can be is from farm to dinning. It is important for everyone, include vendors and consumers to be aware of microbial risks along the food before we eating to reduce the risks surrounding all the time although as some pathogens may be spread beyond the compliance of five keys to safe food and five keys to safer fruits and vegetables (Lim et al., 2010 and WHO, 2012). In the context of inanimate dry surfaces, some pathogens have high touch surfaces that require a more frequent cleaning regimen. These are not limited to walkway rails doorknob/handle, walkway rails, beds, chairs in patient rooms at health care facilities. These surfaces have high risks of bioburden if not sterilised as it contains a high number of bacteria living on a surface compared to conference rooms, bus seats, communal and public places these have less potential for exposure to pathogens (Sehulster et al., 2004).

\section{References}

[1] BD, (2013). Product catalog, Industrial Microbiology, Helping people live healthy live.59pp.https://www.brunschwigch.com/pdf/downloads/ BD_IndustryCatalog 14.pdf. 59pp.Visited on 19/08/2016.

[2] CFIA, (2016). 10 least wanted Food borne diseases. Http://www.foodsafetynews.com/ 2015/09/the-5-mostdangerous-food borne-pathogens/\#.WDKZyblG3Qw. 10pp. Visited on 23/06/2017.

[3] Chilukoti, B. (2014). World Health Day: 5 common causes of food contamination you should know! http://www.thehealthsite.com/diseases-

conditions/world-health-day-5-common-causes-of-foodcontamination-you-should-know/. Visited on 30/11/2016.

[4] Kramer, A., Schwebke, I. \& Günter Kampf, G. (2006). How long do nosocomial pathogens persist on inanimate surfaces? A systematic review. BioMedCentral Infectious Diseases. 6:130. doi: 10.1186/1471-2334-6-130.

http://www.biomedcentral.com/1471-2334/6/130.

Visited on 2011/2015.

[5] Lawley, R. (2013). Food Safety Watch: The science of Safe

http://www.foodsafetywatch.org/factsheets/aflatoxins/. Visited on 25/11/2017.

[6] Lim, J. Y., Yoon, J. W. \& Hovde, C. J. (2010). A Brief Overview of Escherichia coli O157:H7 and Its Plasmid O157. Journal of Microbiology and Biotechnology, 20(1), pp.5-14.

[7] Ren, H. (2012). Plastic Waste Recycling and Greenhouse Gas Reduction Taking Copenhagen as an example from life cycle assessment perspective. A thesis for award of Master Degree at Aalborg University, Denmark. 89pp.

[8] Sehulster, L.M, Chinn, R.Y.W., Arduino MJ, Carpenter, J., Donlan, R., Ashford, D., Besser, R., Fields, B., McNeil, M.M., Whitney, C., Wong, S., Juranek, D., and Cleveland, J. (2004). Guidelines for environmental infection control in health-care facilities.
Recommendations from CDC and the Healthcare Infection Control Practices Advisory Committee (HICPAC). Chicago IL; American Society for Healthcare Engineering/American Hospital Association.

[9] TEA, (2012). Food safety and sanitation guideline: Restaurant Management http://cte.sfasu.edu/wpcontent/uploads/2012/11/Food-Safety-and -SanitationGuidelines-Restaurant-Management-PPT. pdf. 24pp.Visited on 20/07/2017.

[10]TEA, (2015). Culinary Kitchen Mat Lucan $h$ Calculations. Http://cte.sfasu.edu/wpcontent/uploads/2015/02/Culinary-Kitchen-MathCalculations-PPT.pdf. 13pp. Visited on 30/06/2017.

[11] TEA, (2014). Foundations of Safe Food Purchasing, Receiving and Storage 16pp. http://axtellisd.net/view/619.pdf. Visited on 30/06/2017.

[12] Tong, S. Y. C., Davis, J. S., Eichenberger, E., Holland, T. L. \& Fowler, V. G. (2015). Staphylococcus aureus Infections: Epidemiology, Pathophysiology, Clinical Manifestations, and Management. Clinical Microbiology Reviews, 28(3), pp 603-661. http://doi.org/10.1128/CMR.00134-14.

[13] Yusuf, M. A., Abdul, T.T. \& Hamid, T. A. (2012). Optimization of temperature and $\mathrm{pH}$ for the growth and bacteriocin production of Enterococcus faecium. IOSR Journal of Pharmacy e-ISSN: 2250-3013, p-ISSN: 2319-4219, www.iosrphr.org vol. 2, Issue 6, 2012, pp.49-59.

[14] WHO, (2012). Five keys to growing safer fruits and vegetables: Promoting health by decreasing microbial contamination

[15] Wild, C.P. and Gong, Y.Y. (2010). Mycotoxins and human disease: a largely ignored Global health issue. Carcinogenesis, Vol. 31, Issue 1, pp 71-82, https://doi.org/10.1093/carcin/bgp264.

\section{Volume 6 Issue 12, December 2017}

